\title{
Effectiveness of Inquiry-Based Self Control Learning Model against Increase in Food Hygiene Behaviors through Sanitation Hygiene Subject in Catering Vocational Student
}

\author{
Rita Patriasih \\ Food and Culinary Study Program, Faculty of Education and Vocational Technology \\ Indonesia University of Education, Bandung, INDONESIA \\ ritapatriasih@upi.edu
}

\begin{abstract}
One of the important things to consider in food handling that food safety aspect is ensuring that food produced by the industry not only meets the demands of taste alone, but also can meet the health aspect. The reality was the rapid development of today's food industry had not fully followed by an increase in labour's ability to handle the job safely and healthy. Catering Vocational students is required to produce a workforce that is not only competent in the manufacture of food products and services but also have good basic of food hygiene behaviors. The study used a quasi-experimental method with non- equivalent control group pretest posttest design. The subjects were $\mathrm{X}$ grade student as much as two classes. The results of the study revealed that the Inquiry-Based Self Control model effectively improve student knowledge of food hygiene $(\mathrm{N}-$ gain=0.66). Similarly, food hygiene behavior in the experimental class was experiencing better improvement $(\mathrm{N}$-gain $=0.72)$ compared with the control group $(\mathrm{N}$-gain=0.41). The conclusions that the Inquiry Based Self Control learning models is effective in improving food hygiene behavior in Catering Vocational Students. Thus this model is recommended for use in Hygiene Sanitation subjects to prepare candidates for professional food handlers.
\end{abstract}

Index Terms - inquiry, self control; hygiene behavior.

\section{Introduction}

The processing of food, a food handler has a very large role and have a high enough potential to pollute the food if they does not have good hygiene behavior. Food handlers are those who are directly or indirectly related to food and equipment right from the stage of preparation, cleaning, processing and distribution of food to serve [1]. Application of the principle of food hygiene is an absolute requirement that must be owned by a food handler in the food supply of a qualified health. In Indonesia, $80-85 \%$ of food poisoning caused by human factors [2].

The rapid development of today's food industry had not fully followed by an increase in the ability of workers to handle the job safely and healthy. Eviline revealed the findings of BPOM that $51 \%$ Hospitality (Hotel, Restaurant \& Cafe) serves food that does not comply with food safety standards especially in the application of hand washing [3]. Problems of hygiene, poor sanitation in the food industry in Indonesia is one of the weaknesses of labor in handling the job, and it is an issue that is very alarming and the most common cause of food poisoning cases [4]. Clearly been stated in Permenkes RI on Sanitation Hygiene Catering [1] in which the power caterers should have healthy behavior associated with protection against pollution with food both in terms of how to make contact with food and behavior during food processing.

Application of hygiene-sanitary food handler contained in the food industry, is directly related to the implementation of education in vocational competence Vocational High School Catering as an institution that has a big hand for the creation of human resources engaged in the food industry professionalism. Professional is the mental attitude to be truly appreciate the work and master the various aspects in it as the demands of the labor industry.

In reality it turns out the criteria are not fully met, on the vocational schools in the three provinces of West Java, South Sumatra and North Sulawesi, which states that there are some symptoms that indicate a lack of care and concern of students in the school of hygiene-sanitary [5]. Similarly, the results of research on the Knowledge and Attitudes Hygiene Food Handler in Hospitality Vocational students in Cimahi shows that good understanding of food hygiene was only occupied by $36.8 \%$ and $48.5 \%$ of respondents still entered in the category of pretty [6]. Similarly, Nirmala revealed that the average application of learning outcomes Sanitation Hygiene Practice for Preparing Food Buffet at SMK reached 43.37\% [7].

This fact indicates that Sanitation Hygiene subjects, are still not able to carry such a role is ideal, because the learning objectives are still chained to the cognitive achievement. Achievement of learning outcomes is still limited to the mastery of theory but still has not been accompanied by the application of hygiene behavior in the activities of food processing practices. This happens because the learning model that still chained to the conventional model with the lecture method, moreover, that the subjects of Hygiene Sanitation in the Vocational High School is a theory lesson that its application in cooking activities in the laboratory can't be measured.

Furthermore one model that seems right in learning at school in subjects with hygiene and sanitation is an Inquiry- 
Based Self Control (IBSC) model. This model refers to a model developed Inquiry-oriented processing of information related to the discovery and solving the existing problems in the environment, so that students not only to know but also understand and be moved to do it in daily activities especially in hygiene behavior. The inquiry model is associated with increased cognitive ability in which knowledge is the basis of the formation of a behavior. The reason the rational use of the method of inquiry is that students will gain a better understanding of nutrition and health, and will be more interested in the health behavior if they are actively involved. Investigations conducted by the students are the backbone of the method of inquiry. This investigation focused on understanding the concepts of improving students' thinking process skills. It is believed that understanding the concept is the result of the process of scientific thinking [9].

Self-control is the effect of a person's physical, behavioral, and psychological processes [10]. In addition, the notion of self-control proposed by JP Chaplin, namely, the ability to guide their own behavior; the ability to suppress or inhibit impulses or impulsive behavior (characterizing activities to engage in an activity without reflection/without thinking taste or restraint can't be suppressed). Self-control can be applied to a learning model, called the model of self-control.

Stages in the application of the Inquiry-Based Self Control model are:

1. Orientation stage: Students identify problems, with guidance from the teacher, especially with regard to everyday life situations. Identified problems related to healthy behavior problems a food handler. On this occasion the introduction of principles of behavior, self-control and build students' willingness to participate

2. Hypothesis Stage: Activity formulate a hypothesis formulated antiseden and clear as possible as a consequence of the explanations that have been proposed.

3. Definition stage: Clarifying the hypotheses that have been proposed in a class discussion forum for response. In this stage constructed footing in formulating the specific behavior being targeted. Setting a schedule of steps and measurements and make notes of control stimuli.

4. Exploration stage: Hypothesis expanded study in terms of its implications on the assumption that developed from the hypothesis. Structured program of self-control and set shortterm goals and long-term notes program in writing.

5. Evidencing stage: Facts and evidence collected to find support for the hypothesis or testing. At this stage, monitoring behavioral improvement by involving other students to progress reviewed.

6. Generalization stage: Event has reached the stage of inquiry came to the conclusion in the form of problem solving behavior change.

Specifically, excess of IBSC learning model is intended to emphasize the variation in students' learning experiences through a variety of methods and media, among others: the analysis of the case, direct instruction, discussion, modeling, practice expressing ideas, and self-evaluation. All components are presented through a variety of learning experiences in an integrated manner.

Through IBSC model of on this learning students may be invited to work together to be able to search for information and formulate and solve problems related to the importance of having good behavior with regard to the personal hygiene of food handlers. Active student involvement with arouse curiosity and invite students to discuss the problems and find solutions together to make the decision to overcome these problems can stimulate students to have a deeper understanding of the need for healthy behavior. Thus, students are expected to not only know and understand, but also realized the need for personal hygiene and be moved by itself to live it in daily life.

\section{Method}

Quasi experiment method used in this research with nonequivalent control group design in one experimental group and one control group. The population were students of Vocational High school 3 (SMKN 3) Cimahi Catering Service Study Program amounting to 4 classes. Samples to be used as research subjects taken two classes of class X-JB1 and X-JB2 the number of individual students as many as 35 people who will serve as the experimental and control class. The experiment conducted over 4 weeks since March-April 2014.

First performed an analysis of the instrument relating to the validity, reliability, level of difficulty and quality of the distinguishing power. Collected data is processed to determine differences in learning outcomes in the treatment group and the control group. If the data showed normal distribution and homogeneous, then testing using parametric statistical tests, namely through the t-test with a 5\% error level. Gain test was conducted to see the effectiveness of the Inquiry Based Self Control learning model at Hygiene Sanitation lessons.

\section{Result and Discussion}

\section{a. Instrument Test}

\section{1) Instruments Analysis of Food Hygiene Knowledge}

The research instruments tested this time in the form of multiple choice objective test which consists of 20 items with 5 options possible answers, followed by 35 people who have studied the matter before food contamination. Tests were first carried out is to test the validity of knowledge about food hygiene. Retrieved $\mathrm{r}-\mathrm{x}-\mathrm{y}$ for knowledge about food hygiene at 0.62 . It can be concluded that the question of food hygiene knowledge has validity criteria "moderate".

Furthermore, the reliability test knowledge of food hygiene, known reliability coefficient of 0.752 . thus, it can be seen that the instrument has a food hygiene knowledge of reliability criteria are "high" [12]. Then, test the level of difficulty, obtained difficulty index of about 0.68 pretest so that it can be concluded that the criteria for the level of difficulty of the instrument about food hygiene knowledge is "moderate". Recent test conducted to determine the quality of the distinguishing features of the instrument about the pretest and posttest. Index distinguishing the pretest about 0.65 so it can be concluded that the quality of instruments distinguishing qualities distinguishing "good". 


\section{2) Instruments Analysis of hygiene behavior}

The research instruments tested this time of the observation in the form of performance criteria that observed to 35 people who had been doing the practice of food. Validation of 0.732 indicates that the instrument can be concluded that the instrument has a food hygiene behavior validity criteria "high".

Furthermore, the reliability test and reliability coefficients obtained at 0.690 so, it can be stated that the instrument has a food hygiene behaviors reliability criteria are "moderate" [13].

b. Experimental result

Normality Test Hygiene Awareness indicates that the data are normally distributed with details of Hygiene Knowledge probability value for score pree test experiment class is 0.117 $>0.05$, scores post test experiment class is $0.021>0.05$, scores pree test control class is $0.011>0.05$ and scores post test control class is $0.200>0.05$. All data indicate are upper 0.05 so that it can be said normally distributed data.

Based on SPSS 16 output for homogeneity test values obtained significance value of Hygiene Knowledge pre test experiment class based on the variable value of Hygiene Knowledge pre test control class of $0.782>0.05$, meaning that the data variables the same variant.

T-test was conducted to determine the power difference in learning outcomes in second grade after grade IBSC model on treatment as listed in the following table.

TABLE I. RESULTS OF T-TEST KNOWLEDGE OF HYGIENE

\begin{tabular}{|c|c|c|c|c|}
\hline & \multirow{2}{*}{ Class } & \multicolumn{2}{|c|}{ t-test } & \multirow{2}{*}{ Conclution } \\
\hline & & $\mathrm{t}$ & $\mathrm{t}_{\text {table }}$ & \\
\hline Pre test & $\begin{array}{l}\text { Experiment } \\
\text { Control }\end{array}$ & 0.258 & & $\mathrm{H}_{0}$ : received \\
\hline Posttest & $\begin{array}{l}\text { Experiment } \\
\text { Control }\end{array}$ & 6.596 & 2.032 & $\mathrm{H}_{0}$ : rejected \\
\hline
\end{tabular}

Based on the table. 1 the results of the $t$ test for pre test knowledge gained Hygiene $\mathrm{t}=0.258<\mathrm{t}$ table $=2.032$, it can be concluded that there is no significant difference between the pretest experimental class and control class. It means that the initial state and the experimental class students before learning control class has the same ability. As for the post test results test, $\mathrm{t}=6.596>\mathrm{t}$ table $=2.032$, it can be concluded that there are significant differences between the post-test experimental class and control class. That means the state graders experiment and control classes have different capabilities after learning implementation IBSC model.

TABLE.2. THE RESULTS OF FOOD HYGIENE KNOWLEDGE GAIN

\begin{tabular}{lcc}
\multicolumn{3}{c}{ INDEX } \\
\hline \multicolumn{1}{c}{ Class } & Gain & Category \\
\hline Experiment & 0.66 & moderate \\
Control & 0.39 & low \\
\hline
\end{tabular}

Food hygiene knowledge in the experimental class had experienced an increase better $(\mathrm{N}$-gain $=0.66)$ is compared with the control group $(\mathrm{N}$-gain $=0.39)$.

TABLE.3.THE RESULTS OF T TEST HYGIENE BEHAVIOUR

\begin{tabular}{|c|c|c|c|c|}
\hline & \multirow{2}{*}{ Class } & \multicolumn{2}{|c|}{ t- test } & \multirow{2}{*}{ conclusion } \\
\hline & & $\mathrm{t}$ & $\mathrm{t}_{\text {table }}$ & \\
\hline \multirow[t]{2}{*}{ Pre test } & Experiment & & \multirow{4}{*}{2.032} & $\mathrm{H}_{0}$ : \\
\hline & Control & 1.541 & & received \\
\hline \multirow[t]{2}{*}{ Post test } & Experiment & 5.314 & & $\mathrm{H}_{0}:$ \\
\hline & Control & & & rejected \\
\hline
\end{tabular}

According to the table 3 for the pre test is obtained $\mathrm{t}=$ $1.547<\mathrm{t}$ table $=2.032$, it can be concluded that there is no significant difference between the pre-test experimental classes and control classes. It means that the initial state of students in experimental classes and control classes before learning has the same ability. As for the post test results obtained $\mathrm{t}=5.312>\mathrm{t}$ table $=2.032$, thus it can be concluded that there are significant differences between the post test experimental class and the control class. It shows the state of the experimental class students and grade control has different capabilities after learning implementation of IBSC model.

TABLE.4. FREQUENCY DISTRIBUTION OF BEHAVIOR FOOD HYGIENE IN PERCENT

\begin{tabular}{lcccccccc}
\hline & \multicolumn{3}{c}{ Experiment class } & \multicolumn{3}{c}{ Control class } \\
\cline { 2 - 9 } Category & \multicolumn{2}{c}{ before } & \multicolumn{2}{c}{ after } & \multicolumn{2}{c}{ before } & \multicolumn{2}{c}{ after } \\
\cline { 2 - 9 } & $\mathrm{n}$ & $\%$ & $\mathrm{n}$ & $\%$ & $\mathrm{n}$ & $\%$ & $\mathrm{n}$ & $\%$ \\
\hline \multirow{2}{*}{ Good } & 5 & 14.3 & 21 & 60 & 7 & 20.0 & 12 & 34.2 \\
Moderate & 20 & 57.1 & 14 & 40 & 16 & 45.7 & 17 & 48.7 \\
Less & 10 & 28.6 & 0 & 0 & 12 & 34.3 & 6 & 17.1 \\
\hline \multicolumn{1}{c}{ Sum } & 35 & 100 & 35 & 100 & 35 & 100 & 35 & 100 \\
\hline
\end{tabular}

Table 4 above reveals that the increase in the percentage of hygiene behavior for students in the experimental class is higher than students in control class. In the experimental class students who have good hygiene behavior which was originally only $14.4 \%$ increase to $60 \%$, meaning there has been increased by $25.6 \%$ while the control class improvement of hygiene behaviors are becoming both just happen by $14.2 \%$, which is all $20 \%$ to $34.2 \%$.

TABLE. 5. THE RESULTS OF FOOD HYGIENE BEHAVIOR GAIN INDEX

\begin{tabular}{ccc} 
Class & Gain value & Category \\
\hline Experiment & 0.72 & Moderate \\
Control & 0.41 & Low \\
\hline
\end{tabular}

Table 5 above reveals that the food hygiene behavior in the experimental class had experienced an increase better $(\mathrm{N}-$ gain $=0.72)$ is compared with the control group ( $\mathrm{N}$-gain= $0.41)$. 


\section{Conclusions}

Results of $t$ tests revealed that before deploying the model ISBC no difference between the experimental and control class students. But the results of the t test analysis of post-test values there is a difference in the ability of these two classes after applied IBSC models in the experimental class.

$\mathrm{N}$ gain analysis results revealed that the application of the IBSC model on Sanitation Hygiene lessons can improve students' hygiene knowledge and behavior better than conventional models.

Inquiry Based Self Control Learning Model is effective in improving food hygiene behavior in vocational students.

\section{Acknowledgment}

Thank you for SMK 3 Cimahi that has given researchers the opportunity to conduct experiments in this study, particularly for teachers teaching teachers in class X Sanitation Hygiene Catering.

\section{References}

[1] Menkes RI. Regulation of the Minister of Health of the Republic of Indonesia 1096/Menkes/Per/Vi/2011 about Sanitation Hygiene Catering Service. Jakarta: Ministry of Health RI; 2011.

[2] Purnawijayanti. Hygiene of Food Handlers for Food Safety. Proceedings of the National Seminar on Traditional Food Construct Image.Semarang: Universitas Negeri Semarang; 2007.

[3] Eviline, S. M. 51\% of Hotel Foods are Not Clean. Harian Nasional. Retrieved Apr 06, 2014, Avaliable from http://www.hariannasional.com/index.php/umum/kesra/51-persenmakanan-hotel-tak-bersih.

[4] Masdarini, L., \& Mazarina D. Understanding, Attitude and Sanitation Hygiene Student Performance in Food Processing and Presentation of Vocational High School in Catering Service Study Program. Jurnal Teknologi Dan Kejuruan, Vol. 34, No. 2, Sep 2011: 165, p. 178.

[5] Lisyani. Health, Food and Beverage Management Archipelago. Jurnal Sains \& Teknologi, (online) Vol XV No. 2. 2008. Avaliable from http://www.Jakarta.ac.id

[6] Patriasih, R. Study on Knowledge and Attitude Hygiene Food Handler on Vocational Students Catering. Proceedings of the National Seminar $\mathrm{V}$ Bosaris. UNESA, Jun (p.26-33). Surabaya: Universitas Negeri Semarang; 2013,

[7] Nirmala, S. Application of Learning Outcomes salvation and Sanitation Hygiene at Work Practices for Preparing Food Buffet.[Skripsi] Bandung: Indonesia Universitas of Education; 2012

[8] Gaman, P.M. \& Sherrington, K.B. The science of food. 4th ed. Bath Press: United States of America; 2006.

[9] Blosser, P. E. The Role of Laboratory Science Teaching. Columbia Ohio State University; 1990

[10] Calhoun, J.F. Acocella, J.R. Psychology of Adjustment and Human Relationship. New York: McGraw-Hill, Inc; 1990

[11] Aiken R. Lewis. Psychological testing and assessment.8th ed. Massachusetts: A Division of Simon \& Schuster. Inc; 1994.

[12] Ruseffendi, E. T. Introduction To Helping Teachers Develop Competence in Teaching Mathematics to Improve CBSA. Bandung: Tarsito; 2006 